Samuka Vol 5 No 2 : hlm 114-124

SAMUKA

Jurnal Samudra Ekonomika

https://ejurnalunsam.id/index.php/jse

\title{
ANALISIS PENGARUH PERTUMBUHAN EKONOMI, UPAH MINIMUM DAN INDEKS PEMBANGUNAN MANUSIA TERHADAP TINGKAT PENGANGGURAN DI SUMATERA UTARA
}

\author{
${ }^{1}$ Aisyaturridho, ${ }^{2}$ Ahmad Albar Tanjung, ${ }^{3}$ Weni Hawariyuni \\ Email: aisyaturridho96@gmail.com \\ 1,2,3 Fakultas Ekonomi dan Bisnis, Universitas Sumatera Utara, Medan
}

Received: September 2021; Accepted: September 2021; Published: September 2021

\begin{abstract}
This study aims to test empirically the effect of economic growth, minimum income and the human development index (IPM) on the open unemployment rate on 2017-2020 in North Sumatra Province. This study uses time series and cross section data from 2017 to 2020 from BPS North Sumatra. For data analysis using Panel Data Analysis Method which is based on data processing using the software program E-views 10. The results showed a value of $R^{2}$ is 0.94 . This means that $94 \%$ of the proportion of the independent variables used is able to explain the variation in the dependent variable in the model, while the remaining $6 \%$ is explained by other variables not used in this study. All independent variables have a P-value less than 0.05. This means that all the independent variables used in the estimation of this analysis model, namely economic growth, minimum income and the human development index (IPM) together have a significant effect on unemployment in North Sumatra. To reduce the open unemployment rate, the government must increase the economic growth and human development index, while the minimum income must be stabilized in order to reduce the open unemployment rate.
\end{abstract}

Keywords: Open Unemployment Rate, Economic Growth, Minimum income, IPM. PENDAHULUAN

Pengangguran merupakan masalah yng dihadapi oleh semua Negara, baik Negara maju maupun berkembang. Namun hal yang membedakannya adalah, jika di negara maju pengangguran akan dijamin oleh negara sedangkan di negara berkembang tidak. Adapun pengertian dari tingkat pengangguran menurut Sukirno (2006) adalah masalah yang memiliki dampak negatif terhadap perekonomian dan masyarakat.

Maraknya PHK (Pemutusan Hubungan Kerja) saat ini meresahkan berbagai golongan, baik dari sisi perusahaan maupun dari kaum buruh. Dan itu akan berdampak pada perekonomian suatu negara. Fenomena pengangguran ini perlu untuk dilakukan penelitian dan juga analisa, karena dengan adanya pengangguran yang merupakan masalah pokok yang dapat menimbulkan gejolak sosial dan politik yang akan mengganggu kestabilan perekonomian suatu negara. Pengangguran mampu menurunkan tingkat kesejahteraan masyarakat yang diindikasikan dengan menurunnya daya beli masyarakat dikarenakan tidak memiliki penghasilan sehingga tidak mampu melakukan aktivitas konsumsi.

Mengurangi tingkat pengangguran bukanlah hal yang mudah, beberapa program pemerintah yang direncanakan dapat menanggulangi pengangguran belum bisa diwujudkan 
sesuai dengan saran, sehingga pengangguran menjadi hal yang sangat penting dalam pembangunan ekonomi di Provinsi Sumatera Utara.

Adapun beberapa faktor yang menyebabkan pengangguran ini terus bertambah dalam penelitian Riza dan Fivien (2017) diantaranya jumlah penduduk, pertumbuhan ekonomi, indeks pembangunan manusia, upah minimum dan inflasi. Namun dalam penelitian kali ini hanya 3 variabel yang diambil yaitu, pertumbuhan ekonomi, upah minimum dan indeks pembangunan manusia.

Berdasarkan teori, pertumbuhan ekonomi dan tingkat pengangguran memiliki hubungan yang negatif. Dimana ketika pertumbuhan ekonomi meningkat, maka akan mengurangi tingkat pengangguran. Pertumbuhan ekonomi dikarenakan adanya penambahan pada GDP, GDP itu sendiri adalah produk nasional yang diwujudkan oleh faktor-faktor produksi di dalam negeri (milik warga negara dan orang asing) dalam sesuatu negara (Sukirno, 1994). Pertumbuhan ekonomi melalui GDP yang meningkat, diharapkan dapat menyerap tenaga kerja di negara tersebut, karena dengan kenaikan pendapatan nasional melalui GDP kemungkinan dapat meningkatkan kapasitas produksi. Hal ini mengindikasikan bahwa penurunan GDP suatu negara dapat dikaitkan dengan tingginya jumlah pengangguran di suatu negara (Mankiw, 2000).

Indikator selanjutnya yang mempengaruhi tingkat pengangguran adalah Upah minimum. Upah minimum yang ditetapkan oleh pemerintah provinsi Sumatera Utara terus mengalami peningkatan dari tahun ke tahun. Menurut Kaufman dan Hotchkis dalam Alghofari (2011) dijelaskan bahwa dengan tingginya upah minimum yang ditetapkan maka biaya output yang dikeluarkan oleh suatu perusahaan akan semakin besar, hal ini yang menyebabkan perusahaan melakukan efisiensi yang mengurangi tenaga kerjanya. Sehingga semakin menaikkan tingkat pengangguran. Dapat disimpulkan bahwa upah minimum berpengaruh positif terhadap tingkat pengangguran.

Indeks pembangunan manusia juga dapat mempengaruhi tingkat pengangguran. Indeks pembangunan manusia adalah pengukuran, perbandingan dari angka harapan hidup, melek huruf, pendidikan dan standar hidup untuk semua Negara seluruh dunia (Rayana, 2020) Menurut Napitupulu dalam Dwi Mahroji (2019), indeks pembangunan manusia memuat tiga dimensi penting dalam pembangunan yaitu terkait dengan aspek pemenuhan kebutuhan akan hidup panjang umur dan hidup sehat, untuk mendapatkan pengetahuan dan mampu memenuhi standar hidup layak. Semakin baik tingkat kesehatan tenaga kerja, pengetahuan yang tinggi dan memperoleh hidup yang layak, maka hasil kerja akan semakin bagus dan berkualitas, justru sebaliknya semakin buruk keadaaan tenaga kerja, maka hasil pekerjaannya akan semakin buruk pula atau tidak berkualitas. Dengan memperbaiki 3 dimensi tersebut diharapkan mampu meningkatkan kualitas sumber daya manusia agar siap bekerja dan mampu mengurangi tingkat pengangguran di suatu wilayah. Dengan ini dapat disimpulkan bahwa, IPM berpengaruh negatif terhadap tingkat pengangguran.

Pemilihan ketiga variable ini dikarenakan, dari penelitian terdahulu variabel pertumbuhan ekonomi, upah minimum dan indeks pembangunan manusia memiliki pengaruh signifikan dalam penurunan tingkat pengangguran. Seperti pada penelitian, Indra Suhendra (2016), dan Dwi Mahroji (2019), yang mengatakan bahwa hubungan variabel pertumbuhan ekonomi, upah minimum dan indeks pembangunan manusia, terhadap tingkat pengangguran sesuai dengan teori yang berlaku saat ini. Sedangkan dalam penelitian Farid Nugraha (2017), dan Dian Priastiwi (2019), pertumbuhan ekonomi, upah minimum dan indeks pembangunan manusia terhadap tingkat pengangguran memiliki hubungan yang bertolak belakang dengan teori yang berlaku saat ini. 


\section{METODE PENELITIAN}

Jenis Penelitian

Penelitian ini merupakan penelitian kuantitatif dengan pendekatan penelitian yang digunakan adalah pendekatan ekonometrika menggunakan regresi data panel. Dalam penelitian ini menggunakan data sekunder time series dan cross section dari tahun 2017-2020 dengan 33 Kabupaten/Kota yang sumbernya didapat dari BPS, dan juga beberapa data pendukung dari jurnal, penelitian sebelumnya dan buku. Variabel yang digunakan dalam penelitian ini adalah, Tingkat Pengangguran, Pertumbuhan Ekonomi, Upah Minimum dan Indeks Pembangunan Manusia

\section{Metode Analisis Data}

Adapun model yang digunakan untuk menganalisis pengaruh variabel independen terhadap variabel dependen menggunakan model ekonometrika. Berikut merupakan model persamaan yang difungsikan:

$$
\mathrm{Y}=\mathrm{f} \text { (Pertumbuhan Ekonomi, Upah Minimum, IPM) }
$$

\section{Analisis Data Panel}

Penelitian kali ini menggunkan regresi data panel. Hal ini dikarenakan data pada penelitian ini merupakan gabungan cross sections observations dan time series observations yang diperoleh dan diteliti sejalan dengan perjalanan waktu. Metode panel data ini mempunyai ruang dan dimensi waktu, sehingga estimasi variabel dan hasil perhitungan akan memberikan analisa empiris yang lebih luas.

2. Metode Pooled Least Square (PLS)

Model ini sama seperti model regresi sederhana biasa. Di mana data cross section dan time series digabungkan dalam bentuk data panel dan kemudian data tersebut diregresikan dengan menggunakan metode OLS. Walaupun penggabungan ini akan menghasilkan data pengamatan yang lebih banyak sehingga hasil regresi cenderung akan lebih baik dibandingkan regresi yang hanya menggunakan data cross section atau time series saja. Akan tetapi, dengan menggabungkan data, maka kita tidak dapat melihat perbedaan baik antar individu maupun antar waktu. Hal ini tentunya kurang sesuai dengan tujuan digunakannya data panel.

Di samping itu, berdasarkan persamaan di bawah terlihat bahwa intercept maupun slope tidak berubah baik antar individu maupun antar waktu. Secara sistematis model PLS dinyatakan sebagai berikut:

$Y_{i t}=\beta_{0}+\beta_{1} X_{\text {lit }}+\beta_{2} X_{2}$ it $+\ldots+\varepsilon_{i t}$

Untuk mengatasi permasalahan tersebut, ada dua buah teknik yang biasanya digunakan untuk membuat model dari data panel, yaitu model efek tetap (the fixed effect model) dan model efek random (the random effect model).

\section{Metode Efek Tetap (Fixed Effect Model)}

Telah dinyatakan di atas bahwa asumsi pembuatan model yang menghasilkan $\alpha$ konstan untuk setiap individu $(i)$ dan waktu $(t)$ kurang realistis. Dalam metode efek tetap (FEM) kita dapat mengatasi hal tersebut, karena metode ini memungkinkan adanya perubahan $\alpha$ pada setiap $i$ dan $t$. Secara sistematis model FEM dinyatakan sebagai berikut:

$Y_{i t}=\beta_{0}+\beta_{1} X_{i}+\gamma_{2} W_{2 t}+\gamma_{3} W_{3 t}+.+\gamma_{N} W_{N t}+\delta_{2} Z_{i 2}+\delta_{3} Z_{i 3}+.+\delta_{T} Z_{i T}+\varepsilon_{i t}$. (3.4)

Dari model di atas terlihat bahwa sesungguhnya FEM adalah sama dengan regresi yang menggunakan Dummy Variable sebagai variabel bebas, sehingga dapat diestimasi 
dengan Ordinary Least Square (OLS). Dengan estimasi tersebut, maka akan diperoleh estimator yang tidak bias dan konsisten.

\section{Metode Efek Random (Random Effect Model)}

Sebagaimana telah kita ketahui bahwa pada metode efek tetap, perbedaan karakteristik individu dan waktu diakomodasikan pada intercept sehingga interceptnya berubah antar individu dan antar waktu. Sementara metode efek random (REM) perbedaan karakteristik individu dan waktu diakomodasikan pada error dari model. Mengingat ada dua komponen yang mempunyai kontribusi pada pembentukan error, yaitu individu dan waktu, maka random error pada REM juga perlu diurai menjadi error untuk komponen individu, error komponen waktu dan error gabungan Secara sistematis model REM dinyatakan sebagai berikut:

$$
Y_{i t}=\beta_{0}+\beta_{1} X_{i t}+\varepsilon_{i t} ; \quad \varepsilon_{i t}=u_{i}+v_{t}+w_{i t} \ldots \ldots \ldots \text { (3.5) }
$$

Melihat persamaan di atas, maka dapat dinyatakan bahwa REM menganggap efek rata-rata dari data cross section dan time series direpresentasikan dalam intercept. Sedangkan deviasi efek secara random untuk data time series direpresentasikan dalam vt dan deviasi untuk data cross section dinyatakan dalam ui.

5. Pemilihan Model Data Panel

Pertimbangan bahwa REM mempunyai parameter lebih sedikit yang mengakibatkan derajat bebasnya lebih besar dibandingkan FEM yang mempunyai parameter lebih sedikit sehingga derajat bebasnya lebih kecil. Akan tetapi FEM juga mempunyai beberapa kelebihan, seperti: FEM dapat membedakan efek individual dan efek waktu dan FEM juga tidak perlu mengasumsikan bahwa komponen error tidak berkorelasi dengan variabel bebas yang mungkin sulit dipenuhi.

Pemilihan antara REM atau FEM juga dapat dilakukan dengan pertimbangan tujuan analisis atau dapat pula kemungkinan data yang digunakan sebagai dasar pembuatan model, hanya dapat diolah oleh salah satu metode saja akibat berbagai persoalan teknis matematis yang melandasi perhitungan. Beberapa pakar ekonometrika membuat pembuktian untuk menentukan model apa yang paling sesuai untuk digunakan dalam data panel. Adapun kesimpulan dari pembuktian tersebut adalah:

a. Jika pada data panel jumlah data time series lebih besar dibandingkan jumlah data cross section, maka disarankan untuk menggunakan model Metode Efek Tetap (FEM).

b. Jika pada data panel jumlah data time series lebih sedikit dibandingkan jumlah data cross section, maka disarankan untuk menggunakan model Metode Efek Random (REM).

\section{Uji Chow}

Untuk mengetahui model Pooled Least Square (PLS) atau Metode Efek Tetap (FEM) yang akan dipilih untuk estimasi data dapat dilakukan dengan uji F-test atau uji Chow Test. PLS adalah restricted model di mana ia menerapkan intercept yang sama untuk seluruh individu. Seperti yang telah ketahui, terkadang asumsi bahwa setiap unit cross section memiliki perilaku yang sama cenderung tidak realistis mengingat dimungkinkan saja setiap unit cross section memiliki perilaku yang berbeda. Untuk itu dipergunakan Chow Test.

7. Uji Hausman 
Pada dasarnya uji Hausman ini digunakan untuk melihat konsistensi pendugaan dengan OLS. Mengingat REM diduga dengan menggunakan metode tersebut, maka dalam permodelan data panel, uji tersebut dapat digunakan untuk melihat kelayakan penggunaan model panel. Pengujian ini dilakukan untuk menentukan apakah metode efek tetap (FEM) atau metode efek random (REM) yang dipilih. Pengujian ini dilakukan dengan hipotesa sebagai berikut:

$\mathrm{H}_{0}=0$ (menggunakan metode efek random/REM)

$\mathrm{H}_{1} \neq 0$ (menggunakan metode efek tetap/FEM)

Dasar penolakan $\mathrm{H}_{0}$ adalah dengan menggunakan pertimbangan statistik Chi Square. Jika Chi Square statistik > Chi Square table maka $\mathrm{H}_{0}$ ditolak (Model yang digunakan adalah metode efek tetap/FEM), dan sebaliknya.

8. Pengujian Hipotesis

Untuk menguji hipotesis dalam penelitian ini, digunakan uji signifikansi parameter individual (uji parsial t), signifikansi simultan (uji F), dan uji determinasi.

a. Uji t Parsial (Uji Signifikansi Individual)

Uji statistik t pada dasarnya menunjukkan seberapa jauh pengaruh satu variabel independen secara individual apakah mempunyai pengaruh yang signifikan terhadap variabel dependen. Pengujian ini menggunakan tingkat signifikansi 5\% $(\alpha=0,05)$. Kriteria pengujian $\mathrm{t}$ adalah sebagai berikut :

1. Apabila nilai probabilitas signifikansi $<0,05$ maka $\mathrm{H}_{0}$ ditolak dan $\mathrm{H}_{\mathrm{a}}$ diterima yang artinya variabel independen secara parsial berpengaruh terhadap variabel dependen.

2. Apabila nilai probabilitas signifikansi $>0,05$ maka $\mathrm{H}_{0}$ diterima dan $\mathrm{H}_{\mathrm{a}}$ ditolak yang artinya variabel independen secara parsial tidak berpengaruh terhadap variabel dependen.

b. Uji Simultan (Uji Statistik F)

Uji statistik $\mathrm{F}$ bertujuan untuk mengetahui pengaruh variabel independen secara bersama-sama terhadap variabel dependen dengan melihat nilai signifikansi $\mathrm{F}$. Tingkat pengujian $\mathrm{F}$ adalah sebagi berikut :

1. Apabila nilai probabilitas signifikansi $<0,05$ maka $\mathrm{H}_{0}$ ditolak dan $\mathrm{H}_{\mathrm{a}}$ diterima yang artinya variabel independen secara simultan berpengaruh terhadap variabel dependen.

2. Apabila nilai probabilitas signifikansi $>0,05$ maka $\mathrm{H}_{0}$ diterima dan $\mathrm{H}_{\mathrm{a}}$ ditolak yang artinya variabel independen secara simultan tidak berpengaruh terhadap variabel dependen.

c. Uji Koefisien Determinasi $\left(\mathrm{R}^{2}\right)$

Koefisien determinasi $\mathrm{R}^{2}$ pada intinya mengukur seberapa jauh kemampuan model dalam menerangkan variasi variabel dependen. $\mathrm{R}^{2}$ menyatakan koefisien determinasi atau seberapa besar pengaruh variabel independen secara simultan terhadap variabel dependen. Tingkat ketepatan regresi dinyatakan dalam koefisien determinasi majemuk $\left(\mathrm{R}^{2}\right)$ yang nilainya antara 0 sampai dengan 1 . Nilai yang mendekati 1 berarti variabel-variabel independen memberikan hampir semua informasi yang dibutuhkan untuk memprediksi variasi variabel independen. Sedangkan untuk nilai $\mathrm{r}^{2}$ bertujuan untuk mengetahui seberapa jauh kemampuan model dalam menerangkan variasi variabel independen. $r^{2}$ menyatakan koefisien determinasi atau seberapa besar pengaruh variabel independen secara parsial terhadap variabel dependen. 


\section{HASIL DAN PEMBAHASAN}

\section{Hasil}

1. Pemilihan Model Estimasi

a. Uji Chow

Uji Chow digunakan untuk menentukan model terbaik antara pendekatan efek tetap (FEM) dengan pendekatan kuadrat kecil (CEM). Jika Ho diterima, maka pendekatan kuadrat kecil (CEM) yang dipilih, dan sebaliknya jika H1 diterima, maka pendekatan efek tetap (FEM) yang dipilih.

Tabel 1. Uji Chow

\begin{tabular}{crrr}
\hline \hline Effects Test & Statistic & d.f. & Prob. \\
\hline \hline Cross-section F & 31.416082 & $(32,96)$ & 0.0000 \\
Cross-section Chi-square & 322.068342 & 32 & 0.0000 \\
\hline \hline
\end{tabular}

Sumber: E-Views Diolah (2021)

Dapat dilihat pada Tabel 1 bahwa nilai probability F sebesar $0,0000<0,05$, maka H1 diterima yaitu Pendekatan Efek Tetap (FEM) yang lebih baik daripada Pendekatan Kuadrat Kecil (CEM). Oleh karena FEM yang terpilih, maka pengujian dilanjutkan ke Uji Hausman untuk membandingkan FEM dengan REM.

b. Uji Hausman

Uji Hausman digunakan untuk menentukan model terbaik antara pendekatan efek tetap (FEM) dengan pendekatan efek acak (REM). Jika H0 diterima, maka pendekatan efek acak (REM) yang diterima, dan jika H1 diterima, maka pendekatan efek tetap (FEM) yang diterima. Hasil dari Uji Hausman dapat dilihat pada Tabel 2, sebagai berikut:

Tabel 2. Uji Hausman

\begin{tabular}{crrr}
\hline \hline Test Summary & Chi-Sq. Statistic & Chi-Sq. d.f. & Prob. \\
\hline \hline Cross-section random & 20.708535 & 3 & 0.0001 \\
\hline \hline
\end{tabular}

Sumber: E-views Diolah (2021)

Dari hasil Uji Hausman, dapat dilihat bahwa nilai $P$-Value sebesar 0,0003 $>0,05$ maka H1 diterima, sehingga teridentifikasi berikutnya bahwa FEM lebih tepat dari REM.

\section{Hasil Estimasi dan Interpretasi}

Berdasarkan hasil dari Uji Hausman, model estimasi terbaik yang diperoleh adalah pendekatan efek tetap (FEM). Berikut adalah hasil estimasi pendekatan efek tetap (FEM). 


\section{Tabel 3. Fixed Effect Model}

\begin{tabular}{|c|c|c|c|c|}
\hline \multicolumn{5}{|c|}{$\begin{array}{l}\text { Jependent Variable: PNG? } \\
\text { Method: Pooled Least Squares } \\
\text { Date: } 07 / 18 / 21 \text { Time: } 15: 51 \\
\text { Sample: } 20172020 \\
\text { Included observations: } 4 \\
\text { Cross-sections included: } 33 \\
\text { Total pool (balanced) observations: } 132 \\
\end{array}$} \\
\hline Variable & Coefficient & Std. Error & t-Statistic & Prob. \\
\hline LOG(PDRB?) & -24.14609 & 5.967058 & -4.046566 & 0.0001 \\
\hline LOG(UM?) & 8.005012 & 2.234153 & 3.583018 & 0.0005 \\
\hline IPM? & 0.997629 & 0.492112 & 2.027240 & 0.0454 \\
\hline C & 534.7892 & 143.9856 & 3.714187 & 0.0003 \\
\hline \multicolumn{5}{|c|}{ Effects Specification } \\
\hline \multicolumn{5}{|c|}{ Cross-section fixed (dummy variables) } \\
\hline R-squared & 0.941869 & \multicolumn{2}{|c|}{ Mean dependent var } & 4.784924 \\
\hline Adjusted R-squared & 0.920676 & \multicolumn{2}{|c|}{ S.D. dependent var } & 2.755320 \\
\hline S.E. of regression & 0.776023 & \multicolumn{2}{|c|}{ Akaike info criterion } & 2.557731 \\
\hline Sum squared resid & 57.81231 & \multicolumn{2}{|c|}{ Schwarz criterion } & 3.343950 \\
\hline Log likelihood & -132.8103 & \multirow{2}{*}{\multicolumn{2}{|c|}{$\begin{array}{l}\text { Hannan-Quinn criter. } \\
\text { Durbin-Watson stat }\end{array}$}} & 2.877215 \\
\hline F-statistic & 44.44151 & & & 2.316745 \\
\hline Prob(F-statistic) & 0.000000 & & & \\
\hline
\end{tabular}

Sumber: E-Views Diolah (2020)

Berdasarkan hasil pengujian pada tabel 4.8 maka diperoleh hasiluji signifikansi yaitu sebagai berikut:

$$
\begin{array}{ll}
\mathrm{PNG} & =534.7892-24.14609+8.005012+0.997629 \\
\mathrm{t}-\mathrm{sig} & =(0.0003)(0.0001)(0.0005)(0.0454)
\end{array}
$$

Hasil estimasi pendekatan efek tetap (FEM) menunjukkan variabel PDRB atau Produk Domestik Regional Bruto berpengaruh negatif dan signifikan terhadap variabel Tingkat Pengangguran Terbuka kabupaten/kota di Provinsi Sumatera Utara dengan nilai sebesar 24.14609, artinya setiap penambahan 1 persen PDRB akan menurunkan Tingkat Pengangguran Terbuka sebesar 24 persen. Nilai Prob. dari variabel PDRB sebesar $0.0001<$ 0,05 menunjukkan variabel PDRB berpengaruh signifikan terhadap variabel Tingkat Pengangguran Terbuka.

Variabel UM atau Upah Minimum berpengaruh positif dan signifikan terhadap Tingkat Pengangguran Terbuka kabupaten/kota di Provinsi Sumatera Utara dengan nilai sebesar 8.005012, artinya setiap penambahan 1 persen Upah Minimum akan menurunkan Tingkat Pengangguran Terbuka sebesar 8 persen. Nilai Prob. dari variabel Upah Minimum sebesar $0.0005<0,05$ menunjukkan variabel Upah Minimum berpengaruh signifikan terhadap variabel Tingkat Pengangguran Terbuka.

Variabel IPM atau Indeks Pembangunan Manusia berpengaruh positif dan signifikan terhadap Tingkat Pengangguran Terbuka kabupaten/kota di Provinsi Sumatera Utara dengan nilai sebesar 0.997629 , artinya setiap penambahan 1 indeks pembangunan manusia akan menaikkan Tingkat Pengangguran Terbuka sebesar 0.997629 persen. Nilai Prob. dari variabel indeks pembangunan manusia sebesar $0.0454<0,05$ menunjukkan variabel Indeks 
Pembangunan Manusia berpengaruh signifikan terhadap variabel Tingkat Pengangguran Terbuka.

Nilai R-squared sebesar 0.941869 menunjukkan variabel PDRB, Upah Minimun dan Indeks Pembangunan Manusia memiliki hubungan dengan variabel Tingkat Pengangguran Terbuka sebesar 94,18\%. Nilai Adjusted R-squared sebesar 0.920676 menunjukkan variabel PDRB, Upah Minimum dan Indeks Pembangunan Manusia dapat menjelaskan variabel Tingkat Pengangguran Terbuka sebesar 92,06\% dan sisanya sebesar 7,94\% dijelaskan oleh variabel lain yang tidak disertakan dalam penelitian ini. Nilai Prob(F-statistic) sebesar $0.000000<0,05$ menunjukkan variabel PDRB, Upah Minimun dan Indeks Pembangunan Manusia secara bersama-sama berpengaruh signifikan terhadap variabel Tingkat Pengangguran Terbuka.

\section{Pembahasan}

a. Pengaruh PDRB terhadap Tingkat Pengangguran Terbuka

Berdasarkan hasil estimasi variabel Pertumbuhan Ekonomi berpengaruh negatif dan signifikan terhadap variabel Tingkat Pengangguran Terbuka kabupaten/kota di Provinsi Sumatera Utara, berarti jika Pertumbuhan Ekonomi meningkat maka Tingkat Pengangguran menurun, dan sebaliknya. Hasil estimasi tersebut sesuai dengan hipotesis penelitian yang menyatakan variabel Pertumbuhan Ekonomi berpengaruh negatif terhadap variabel Tingkat Pengangguran Terbuka kabupaten/kota di Provinsi Sumatera Utara, sesuai juga dengan Hukum Okun (Mankiw, 2006), teori ini menyatakan bahwa ada hubungan antara pertumbuhan ekonomi (dalam hal ini PDB) dengan pengangguran. Hukum Okun menyatakan bahwa penurunan tingkat pengangguran sebesar 1 persen setiap ada kenaikan PDB riil mendekati 2 persen. Jika terjadi peningkatan output nasional / daerah dalam hal ini adalah pertumbuhan ekonomi maka akan menyebabkan permintaan tenaga kerja naik dan pengangguran turun.

Penelitian ini juga sejalan dengan penelitian yang telah dilakukan oleh Duma (2017), Ronny (2012), dan Dian (2019), yang mengatakan bahwa pertumbuhan ekonomi memiliki hubungan yang negatif terhadap tingkat pengangguran di Sumatera Utara. Namun penelitian ini bertolak belakang dengan penelitian Nadia (2015) yang mengatakan pertumbuhan ekonomi memiliki hubungan yang positif terhadap tingkat pengangguran di Kota Medan.

b. Pengaruh Upah Minimum Terhadap Tingkat Pengangguran Terbuka

Berdasarkan hasil estimasi variabel Upah Minimum berpengaruh positif dan signifikan terhadap variabel Tingkat Pengangguran Terbuka kabupaten/kota di Provinsi Sumatera Utara, berarti jika Upah Minimum meningkat maka Tingkat Pengangguran juga meningkat, dan sebaliknya. Hasil estimasi tersebut sesuai dengan hipotesis penelitian yang menyatakan variabel Upah Minimum berpengaruh positif terhadap variabel Tingkat Pengangguran Terbuka kabupaten/kota di Provinsi Sumatera Utara, sesuai juga dengan penelitian Alghofari (2010) yang mengatakan Tenaga kerja menetapkan tingkat upah minimumnya pada tingkat upah tertentu. Jika seluruh upah yang ditawarkan besarnya di bawah tingkat upah tersebut, seorang pekerja akan menolak mendapatkan upah tersebut dan hal ini akan menyebabkan terjadinya pengangguran. Jika upah yang ditetapkan pada suatu daerah terlalu rendah, maka akan berakibat tingginya jumlah pengangguran yang terjadi pada daerah tersebut. Apabila ditinjau dari sisi pengusaha, meningkatnya upah akan meningkatkan biaya yang dikeluarkan oleh perusahaan, maka akan mengurangi efisiensi pengeluaran, sehingga pengusaha akan mengambil kebijakan pengurangan tenaga kerja guna mengurangi biaya produksi. Hal ini akan berakibat pada peningkatan pengangguran. 
Penelitian ini juga sejalan dengang penelitian Ari (2016) yang mengatakan bahwa upah minimum berpengaruh positif terhadap tingkat pengangguran di Kabupaten Aceh Barat. Namun penelitian ini bertolak belakang dengan penelitian yang dilakukan oleh Rully (2018) yang mengatakan bahwa upah minimum mampu mengurangi tingkat pengangguran terbuka di Indonesia.

c. Pengaruh Indeks Pembangunan Manusia Terhadap Pengangguran Terbuka

Berdasarkan hasil estimasi variabel Indeks Pembangunan Manusia berpengaruh positif dan signifikan terhadap variabel Tingkat Pengangguran Terbuka kabupaten/kota di Provinsi Sumatera Utara, berarti jika Indeks Pembangunan Manusia meningkat maka Tingkat Pengangguran juga meningkat, dan sebaliknya. Hasil estimasi tersebut tidak sesuai dengan hipotesis penelitian yang menyatakan variabel Indeks Pembangunan Manusia berpengaruh negatif terhadap variabel Tingkat Pengangguran Terbuka kabupaten/kota di Provinsi Sumatera Utara, Hasil penelitian ini sesuai dengan Teori Pertumbuhan Baru dalam Mahroji (2019) yang menyatakan bahwa perkembangan Indeks Pembangunan Manusia memiliki pengaruh terhadap tingkat pengangguran, namun hasil dari penelitian ini menunjukkan sifat hubungan yang positif antara IPM dan pengangguran, sedangkan pada Teori Pertumbuhan Baru sifat hubungan IPM dan pengangguran adalah negatif. Teori pertumbuhan baru menjelaskan bahwa peningkatan pembangunan manusia melalui pembangunan modal manusia (human capital) yang tergambar dalam tingkat pendidikan dan kesehatan dapat meningkatkan produktivitas manusia dalam melakukan pekrjaan sehingga akan meningkatkan permintaan tenaga kerja dan penurunan pada tingkat pengangguran. Menurut Teori Keynes bahwa melalui peningkatan daya beli masyarakat yang merupakan indikator hidup layak dari indeks pembanguna manusia menunjukkan peningkatan dalam permintaan agregat dapat mempengaruhi kesempatan kerja itu sendiri. Apabila permintan agregat atau secara keseluruhan rendah maka perusahaan akan menurunkan jumlah produksinya dan tidak dapat menyerap kelebihan tenaga kerja sehingga permintaan dan penawaran tenaga kerja hampir tidak pernah seimbang dan pengangguran sering terjadi.

Perkembangan kualitas hidup di Sumatera Utara dapat dikatakan mengalami perbaikkan pada tahun 2017 hingga tahun 2020. Kondisi ini tercermin dari meningkatnya Indeks Pembangunan Manusia (IPM) Provinsi Sumatera Utara sebesar 70,57 (tahun 2017) meningkat bila dibandingkan dengan sebelumnya 70,00 (tahun 2016). Hingga tahun 2020 IPM Provinsi Sumatera Utara mengalami peningkatan menjadi 71,77.

Walaupun perkembangan Indeks Pembangunan Manusia selalu meningkat, namun pengangguran di Sumatera Utara dari tahun 2017-2020 tidak mengalami penurunan. Permasalahan tenaga kerja juga dipengaruhi oleh produktivitas tenaga kerja yakni kualitas dan keterampilan para pencari kerja yang masih rendah bahkan terkadang tidak cocok dengan kualifikasi yang dibutuhkan oleh perusahaan. Selain itu, terbatasnya anggaran juga menjadi kendala bagi pemerintah daerah untuk mengatasi permasalahan ketenagakerjaan yang ada di Sumatera Utara. Faktor inilah yang menyebabkan terjadinya mismatch antara IPM dengan tingkat pengangguran terbuka.

Indikator lainnya yang menunjukkan terjadinya mismatch adalah rendahnya penyerapan lulusan Balai Latihan Kerja (BLK). Pelaksanaan pendidikan dan pelatihan vokasi di Indonesia sebagian besar masih bersifat supply driven. Artinya, sebagian besar lembaga pendidikan dan pelatihan vokasi masih menyelenggarakan pendidikan dan pelatihan vokasi berdasarkan sumber daya yang mereka miliki, tanpa melihat kebutuhan tenaga kerja di dunia usaha dan dunia industri sehingga lulusan tidak dapat terserap karena kompetensi yang dimiliki oleh lulusan lembaga pelatihan tidak sesuai dengan kebutuhan riil dunia usaha dan dunia industri. 
Idealnya pelaksanaan pendidikan dan pelatihan vokasi bersifat demand driven atau selalu menyesuaikan dengan dinamika kebutuhan riil dunia usaha dan dunia industri. Agar dapat bertransformasi dari supply driven ke demand driven, dibutuhkan kebijakan dari pemerintah untuk melibatkan pihak pengguna tenaga kerja dalam pelaksanaan pendidikan dan pelatihan vokasi. Di sisi lain, pendidikan dan pelatihan vokasi yang dilakukan oleh beberapa kementerian dan lembaga belum terintegrasi dengan baik sehingga ketersediaan informasi tentang kompetensi dan jumlah lulusan pendidikan dan pelatihan belum bisa diakses oleh kebutuhan dunia usaha dan industri. Di samping itu, belum adanya kesamaan persepsi terkait dengan standardisasi dan level dalam penyelenggaraan pendidikan dan pelatihan vokasi antar-kementerian.

Sektor penyumbang perekonomian di Provinsi Sumatera Utara yang tertinggi dan terbanyak menyerap tenaga kerja masih di sektor jasa dan yang terendah menyerap tenaga kerja adalah sektor industri. Untuk mengimbangi Indeks Pembangunan Manusia yang sudah bagus seharusnya industri harus lebih dimaksimalkan dalam penyerapan tenaga kerja dan pemerintah harus mampu menjamin ketersediaan lowongan pekerjaan untuk mengurangi tingkat pengangguran yang ada.

Hasil penelitian ini sejalan dengan temuan Muhammad NurCholis (2014) hasil penelitiannya menunjukkan bahwa Indeks Pembangunan Manusia berpengaruh positif dan signifikan terhadap Pengangguran di Provinsi Jawa Timur, dan juga sejalan dengan temuan Muhammad Shun Hajji (2013) hasil penelitiannya menunjukkan bahwa angka melek huruf yang merupakan salah satu indikator dari IPM berpengaruh positif dan signifikan terhadap pengangguran di Provinsi Jawa Tengah hal ini disebabkan karena dengan pendidikan yang tinggi angkatan kerja cenderung memilih milih pekerjaan sehingga menganggur atau bisa juga disebabkan karena kualifikasi angkatan kerja tidak sesuai dengan lowongan pekerjaan yang ada. Hasil penelitian ini tidak sejalan dengan temuan Dwi Mahroji dan Lin Nurkhasanah (2019) hasil penelitiannya menunjukkan bahwa Indeks Pembangunan Manusia berpengaruh negatif dan signifikan terhadap Pengangguran di Provinsi Provinsi Banten.

\section{KESIMPULAN}

Berdasarkan hasil penelitian dapat ditarik kesimpulan sebagai berikut:

1. pertumbuhan ekonomi memiliki pengaruh negatif dan signifikan terhadap tingkat pengangguran di Provinsi Sumatera Utara. Dimana ketika pemerintah mampu menaikkan pertumbuhan ekonomi maka tingkat pengangguran akan menurun.

2. Upah minimum dan indeks pembangunan manusia memiliki pengaruh positif dan signifikan terhadap tingkat pengangguran di Provinsi Sumatera Utara dari tahun 20172020. Pengaruh positif pada upah minimum, dapat diartikan bahwa, setiap kenaikkan upah minimum, maka tingkat pengangguran juga ikut naik.

3. Indeks pembangunan manusia juga memiliki pengaruh yang positif, dapat diartikan bahwa setiap kenaikan indeks pembangunan manusia, maka akan turut menaikkan tingkat pengangguran di Provinsi Sumatera Utara. Berdasarkan penelitian hal ini tidak sesuai dengan teori yang ada, dikarenakan di Sumatera Utara sendiri setiap masyarakat yang memiliki pendidikan yang tinggi, maka masyarakat itu akan lebih selektif dalam memilih pekerjaan apa yang akan dilakukannya. Sehingga waktu menganggurnya akan lebih lama.

\section{REFERENCES}

Alghofari, Farid. 2011. Analisis Tingkat Pengangguran di Indonesia Tahun 1980-2007. Jurnal Pengangguran

Duma. 2017. Analisis Pengaruh Tingkat Pertumbuhan Ekonomi Terhadap Pengangguran Di Sumatera Utara. Jurnal Ilmiah Jurusan Ekonomi. 
Effendy, Rully Sutansyah. 2018. Pengaruh Upah Minimum Terhadap Tingkat Penganguran Terbuka di Indonesia. Jurnal Ilmiah Ekonomi

Firdhania, Riza, Fivien Muslihatinningsih. 2017. Faktor-Faktor yang Mempengaruhi Tingkat Pengangguran di Kabupaten Jember. E-Journal Ekonomi Bisnis dan Akuntansi.

Mankiw, N Gregory. 2000. Pengantar Ekonomi Jilid 1. Jakarta: Erlangga.

Mankiw N,Gregory. 2006. Makro Ekonomi, Terjemahan: Fitria Liza, Imam Nurmawan, Jakarta: Penerbit Erlangga.

Mahroji, Dwi dan Iin Nurkhasanah. 2019. Pengaruh Indeks Pembangunan Manusia Terhadap Tingkat Pengangguran di Provinsi Banten. Jurnal Ilmu Ekonomi

Nugraha, Farid. 2017. Analisis Faktor-Faktor Yang Mempengaruhi Pengangguran Di Provinsi Jawa Tengah Tahun 2012-2014.

Priastiwi, Dian, Herniwati Retno Handayani. 2019. Analisis Pengaruh Jumlah Penduduk, Pendidikan, Upah Minimum, Dan PDRB Terhadap Tingkat Pengangguran Terbuka Di Provinsi Jawa Tengah. Diponegoro Journal of Economics

Siregar, Dwi Rayana, Ahmad Albar Tanjung. 2020. Pengaruh Infrastruktur Dan Indeks Pembangunan Manusia Terhadap Pertumbuhan Ekonomi Kabupaten Langkat 2010-2019. E-Jurnal Matematika.

Suhendra, Indra, Bayu Hadi Wicaksono. 2016. Tingkat Pendidikan, Upah, Inflasi, Dan Pertumbuhan Ekonomi Terhadap Pengangguran Di Indonesia. Jurnal Ekonomi Pembangunan.

Sukirno, Sadono. 1994. Pengantar Ekonomi Makro. Jakarta: PT. Raja Grasindo Perseda.

Sukirno, Sadono. 2006. Makroekonomi Teori Pengantar. Jakarta: PT RajaGrafindo Persada. 